\title{
TRANSITIONAL JUSTICE WITHIN THE FRAMEWORK OF A PERMANENT CONSTITUTION: THE CASE STUDY OF THE LEGAL FRAMEWORK FOR PEACE IN COLOMBIA
}

\author{
Carlos Bernal-Pulido*
}

\begin{abstract}
This article examines a dilemma facing architects of transitional justice processes within the framework of a permanent constitution. According to the dilemma, if the transition is successful the permanent constitution is replaced; if the permanent constitution remains in place, the transition is rendered impossible. The dilemma is illustrated by the 'constitutional replacement doctrine' of the Colombian Constitutional Court, which has held that constitutional amendments (including transitional justice mechanisms) which 'replace' essential principles of the constitution are a species of 'unconstitutional constitutional amendment' and are invalid. There is undeniable logic to this doctrine-a constitutional change which degrades the fabric of a constitution by ousting its underlying principles should require the enactment of a new constitution, rather than a process of amendment. However, applied in a rigid fashion, doctrines of this sort render processes of transitional justice within the framework of a permanent constitution impossible. This in turn presents a major obstacle for both transitional justice and constitutionalism in post-conflict societies. The recent jurisprudence of the Constitutional Court applying the 'replacement doctrine' to the current peace process with the Armed Revolutionary Force of Colombia, however, suggests a middle way: transitional constitutional amendments which might trigger the doctrine are nonetheless constitutional if they are enacted consistently with the international and transnational framework for transitional justice, assessed by means of a balancing test, whereas a strict syllogistic application of the doctrine is called only for in cases of suspected 'abusive constitutionalism'. This article analyzes and endorses the Constitutional Court's revised doctrine. The solution presented here recognizes that, although the design of a successful process of transitional justice is likely to 'replace' the existing constitution with something substantially different, it should be regarded as 'constitutional' if the transitional justice mechanisms only limit essential principles of the permanent constitution in the degree that is required for the adopted mechanisms to achieve their goals. The result is an internationally nuanced notion of 'transitional constitutionalism'.
\end{abstract}

\section{Keywords}

Transitional Constitutionalism, Latin America, Post-conflict Constitutions

\footnotetext{
Associate Professor, Macquarie University Law School (Sydney, Australia). I would like to thank Jason Allen, Pablo de Greiff, and two anonymous reviewers for helpful comments and suggestions on an earlier version of this manuscript, and Jason Allen for editing this text for publication.
}

Copyright $\odot$ the Author(s).

This work is licensed under a Creative Commons Attribution-NonCommercial-NoDerivs 3.0 License. 


\section{Introduction}

A process of transitional justice within the framework of an established constitutional order must reconcile an inherent tension between transition and the enduring nature of a permanent constitution: between fidelity to the existing constitution as an authoritative source of binding norms, on the one hand, and fidelity to the imperatives of political change and transitional justice which motivate the process, on the other. This tension gives rise to a dilemma, which we might call the dilemma of transition within the framework of a permanent constitution, or the 'transitional dilemma'. Either the transition is successful but the constitution is not permanent any more, or the constitution maintains its permanent character but renders the transition impossible. If the transition is successful, then it will bring about major political and institutional changes. These changes will, in substance, undermine the permanent character of the erstwhile constitution. By contrast, if the permanent constitution secures a high level of political and institutional stability during the process, it will render it difficult, if not impossible, for the transitional justice mechanisms to achieve their objectives.

According to the UN Secretary-General's definition, the concept of 'transitional justice' refers to a range of 'processes and mechanisms associated with a society's attempts to come to terms with a legacy of large-scale past abuses, in order to ensure accountability, serve justice and achieve reconciliation.' Through the processes and mechanisms of transitional justice, the political community seeks to overcome a past of severe and systematic violations of human rights, and to 'repair and rebuild' state institutions within the confines of the rule of law. ${ }^{2}$ On this basis, transitional justice generally implies radical political change, often leading to a new constitutional framework punctuated from the old. ${ }^{3}$ As such, transitional justice processes usually take place within an interim legal framework, ${ }^{4}$ designed to ensure the appropriate allocation of responsibility for human

1 K Annan, United Nations Secretary-General, The rule of law and transitional justice in conflict and post-conflict societies: Report of the Secretary-General, UN Doc S/2004/616, 23 August 2004, 4.

2 JE Méndez, 'Constitutionalism and Transitional Justice', in M Rosendelf \& A Sajó (eds), The Oxford Handbook of Comparative Constitutional Law (2012) 1270, 1271.

3 RG Teitel, Transitional Justice (2000) 191ff.

4 Exceptions to this trend are the processes of transition concerning redress practices in established democracies, such as the Apology to Australia's Indigenous Peoples or New Zealand's 
rights violations, acknowledgment of the truth, compensation to victims, demobilisation of individuals and groups in conflict, reconciliation, and to bring about the end of an unjust regime. ${ }^{5}$ Transitional constitutions, such as the 1993 South African Interim Constitution, ${ }^{6}$ provide a framework of this kind. ${ }^{7}$ They are provisional and transformative. They support the undertaking of major institutional reforms and afford flexibility for an inclusive negotiation of new constitutional arrangements. ${ }^{8}$

In this respect, a transitional constitution is different from a permanent constitution, which purports to preserve an organised political community in the form already established, ${ }^{9}$ and to create stability through its endurance over time. $^{10}$ Permanent constitutions are by definition an enduring statement of

Treaty of Waitangi. On these practices, see S Winter, "Towards a Unified Theory of Transitional Justice' (2013) 7 Int J Transitional Justice 225.

5 On the aims of transitional justice, see, JE Méndez, 'Accountability for Past Abuses' (1997) 19 HRQ 255.

${ }^{6}$ For the text, see $<$ http://www.gov.za/documents/constitution/93cons.htm $>$ [accessed 30 July 2014].

${ }^{7}$ Other transitional constitutions are: the Libyan Interim Constitutional Declaration (of 3 August 2011); the Interim Constitution of Nepal (of 15 January 2007); and the Transitional Constitution of South Sudan (of 9 July 2011) - all of which are still valid. See also the Provisional Constitution of the Republic of China (valid from 11 March 1912 to 1 June 1931); the 2011 Provisional Constitution of Egypt (valid from 30 March 2011 to 26 December 2012); the Indian Independence Act 1947 (with regards to Pakistan, until the promulgation of Pakistan's Constitution of 1956); the 1972 Interim Constitution of the Islamic Republic of Pakistan (valid from 17 April to 14 August 1972); the Provisional Constitution of the Confederate States of America (valid from 8 February to 11 March 1861); the Law of Administration for the State of Iraq for the Transitional Period (valid from 28 June 2004 to 15 October 2005); the 1950 Provisional Constitution of Indonesia (valid from 17 August 1950 to 5 July 1959); the Dáil Constitution of Ireland (valid from 21 January 1919 to 6 December 1922); the Interim Constitution of Tanzania (valid from 1964 to 1977); and the Interim Constitution of Thailand (valid from 1 October 2006 to 19 August 2007).

${ }^{8}$ Klare defines transformative constitutionalism as a 'project of constitutional enactment, interpretation, and enforcement committed (not in isolation, of course, but in a historical context of conducive political developments) to transforming a country's political and social institutions and power relationships in a democratic, participatory, and egalitarian direction. Transformative constitutionalism connotes an enterprise of inducing large-scale social change through nonviolent political processes grounded in law'. See KE Klare, 'Legal Culture and Transformative Constitutionalism' (1998) 14 S Af JHR 146, 150.

9 Sunstein has distinguished between transformative and preservative constitutions. According to Sunstein, 'preservative constitutions attempt to protect long-standing practices that it is feared, will be endangered by momentary passions.' In contrast, 'transformative constitutions attempt not to preserve an idealized past but to point the way toward an ideal future'. See CR Sunstein, Designing Democracy: What Constitutions Do (2001) 67-8.

${ }^{10}$ On constitutional endurance, see generally, Z Elkins, T Ginsburg \& J Melton, The Endurance of 
fundamental principles and institutional design intended to protect the political order from change, especially the vagaries of politics and the abuses of public office-holders. Thus, while constitutions may validly be amended, changes that effect a substantial break with an existing constitution can be prima facie inconsistent with it. Changes that touch the basic structure of the constitution, or violate its fundamental principles, would replace, rather than amend it.

Transitional justice within the framework of a permanent constitution presents a dilemma precisely because the choice to effect transition by means of constitutional amendment, rather than through a transitional or interim constitution implies an intention not to break too radically with the existing constitution. It is up to the architects of a constitutional transition to avoid this dilemma by navigating between constitutional stasis and replacement. One of the most remarkable transitional justice processes in this respect is currently taking place in Colombia. The Colombian Government is carrying out peace negotiations with the only remaining guerrilla group in Latin America, the Armed Revolutionary Force of Colombia or 'FARC'. Not only is this process being brought about without a truce between the Government and FARC, it is occurring within the framework of the 1991 Colombian Constitution, which is not a transitional but a permanent constitution. ${ }^{11}$ Rather than introducing an interim or transitional framework, the Colombian government has introduced constitutional amendments to allow negotiations with FARC which, on the face of it, appear to conflict with some of the most basic principles of the permanent Constitution. This article presents the attempt by the Colombian Constitutional Court to mediate this tension in the context of its doctrine against constitutional amendments that displace essential principles of the constitution.

\section{The Colombian 'Legal Framework for Peace'}

In 2012, the incumbent Government and Congress amended the Colombian Constitution to make provision for peace negotiations with the FARC. Legislative Act

National Constitutions (2009).

11 The 1991 Constitution is not 'transformative' in respect of the specific challenge of achieving peace between the Government and the FARC. Challenges facing the negotiation process are: the demobilisation of the guerrilla members; the enforcement of criminal laws concerning ordinary offenses; political crimes and human rights violation perpetrated by them; the adjustment of the political system for enabling their future participation; compensation to victims; and acknowledgment of truth. 
1/2012, also called the 'Legal Framework for Peace', ${ }^{\text {, }}$ introduces two new articles into the Constitution. 'Transitory' Articles 66 and 67 create a number of 'exceptional transitional justice mechanisms', comprising grants of power to Congress: (1) to give special treatment to certain illegal groups compared to the remaining participants in the conflict; (2) to create new judicial and extra-judicial procedures for prosecuting crimes, clarifying the truth, and ensuring compensation to the victims; (3) to create a truth commission; (4) to determine discretionary criteria for prioritising criminal prosecution of those 'most responsible' for war crimes and to refrain from prosecuting other offences and offenders; and (5) to deem certain offences 'political', such that their perpetrators can be eligible for future participation in politics. The Articles neither specify a date at which they will expire, nor a precise period within which Congress ought to exercise them. ${ }^{13}$ Moreover, the Attorney General has so far interpreted the grant of power concerning the prioritisation of criminal prosecutions as the basis for a new general model of criminal investigation. ${ }^{14}$

The adjectives 'transitory' and 'exceptional' create the impression of a transitional constitutional framework for peace. However, the transitory Articles purport neither to derogate nor interrupt the validity of the essential principles of the Constitution, but to subsist within the framework of the permanent Constitution. Prima facie, some of these grants of power appear to be at odds with essential principles of the Constitution, such as the principle of equality and the rule of law. The principle of equality, for example, entrenched in Article 13 of the Constitution, requires equal treatment for all individuals. This is in tension with the first grant of power in Legislative Act $1 / 2012$. The principle of the rule of law, entrenched in Article 1 of the Constitution, requires (among other things) a strict enforcement of criminal laws and the prosecution of all crimes. This is in tension with the fourth empowerment of Legislative Act 1/2012.

This raises difficulties, as the Colombian Constitutional Court has an established 'constitutional replacement doctrine', according to which constitutional amendments inconsistent with the essential principles of the Constitution are

\footnotetext{
${ }^{12}$ In the Colombian Constitution, a Legislative Act is an Act by means of which the Congress amends the Constitution.

${ }^{13}$ There is one exception: Article 2 of the Legislative Act 1/2012 grants only four years to the Congress for enacting a law determining the selection criteria for prioritising criminal prosecutions. Nonetheless, the Article does not determine what would then happen if the Congress does not enact such a law within that time frame.

${ }^{14}$ See, Directive 01/2012 of the Attorney General Office, <http://www.fiscalia.gov.co/colom$\mathrm{bia} / \mathrm{wp}$-content/uploads/Directiva-N\%C2\%B0-0001-del-4-de-octubre-de-2012.pdf> [accessed 19 November 2014].
} 
invalid. ${ }^{15}$ The power to amend the Constitution does not include the power to 'replace' it: while amendments can update constitutional rules, they cannot 'denature' essential elements of the Constitution, that is take away or alter their natural qualities or destroy their basic structure. The creation of privileges for members of a specific guerrilla group and immunities to perpetrators of crimes, would appear to denature or destroy the principles of equality and the rule of law, which are essential constitutional principles. This would appear to demand the conclusion that the transitional justice mechanisms are unconstitutional. In fact, Act 1/2012 has been challenged twice in the Colombian Constitutional Court. In Judgments C-579/2013 and C-577/2014, the Constitutional Court upheld the constitutionality of the Legal Framework for Peace, declaring that it did not fall foul of the replacement doctrine.

The issue has deeper theoretical and practical implications, going beyond the Colombian case. Due to the global spread of constitutionalism and constitutional review in general, ${ }^{16}$ and of the doctrine of unconstitutional constitutional amendments in particular, ${ }^{17}$ it is likely that constitutional courts around the world will be drawn into controversies of this sort in the course of transitional justice processes carried out under the framework of permanent constitutions. Against this background, this paper offers a critical analysis of the way in which the Colombian Constitutional Court attempted to solve the transitional dilemma in Judgments C-579/2013 and C-577/2014. ${ }^{18}$

My aim in this article is to examine the reasoning and outcome of the judgments and explore their relevance for the study of transitional constitutionalism more broadly. Before Judgment C-579/2013, the Constitutional Court applied the constitutional replacement doctrine by means of legal syllogistic reasoning. On this approach, the Court would enquire whether the amendment under review 'denatured' an essential element of the Constitution, for example by derogating an essential principle such as equality. If so, the Court would declare the amendment unconstitutional. In Judgment C-579/2013, the Constitutional Court

${ }^{15}$ On this doctrine, see generally, C Bernal, 'Unconstitutional Constitutional Amendments in the Case Study of Colombia: An Analysis of the Justification and Meaning of the Constitutional Replacement Doctrine' (2013) 11 IJ Con L 339.

${ }^{16}$ See generally, T Ginsburg, 'The Global Spread of Constitutional Review', in GA Caldeira, RD Kelemen \& KE Whittington (eds), The Oxford Handbook of Law and Politics (2008) 81.

${ }^{17}$ See generally, Y Roznai, 'Unconstitutional Constitutional Amendments - The Migration and Success of a Constitutional Idea' (2013) 61 AJCL 657.

${ }^{18}$ At the time of submitting this article, the Constitutional Court has only released a seven page press statement concerning the content of the Judgment C-577/2014 but not the judgment as such. I will base my analysis on the press statement. 
introduced two innovations in the methodology for applying the constitutional replacement doctrine. First, it engaged in a 'balancing' exercise, rather than syllogistic reasoning, in its application of the doctrine. Secondly, in doing so, the Court balanced the Constitution's essential principles against principles it drew from what might be called the international and transnational legal framework for transitional justice'. The aim of this exercise was to determine whether Legislative Act 1/2012 realised the objects of transitional justice enough to justify its degree of encroachment on essential principles of the Constitution. The Court gave a positive answer to this question.

In the sections that follow, I endorse the methodology adopted by the Constitutional Court in Judgments C-579/2013 and C-577/2014 for assessing the constitutionality of transitional justice mechanisms under a permanent constitution. Given that the design of a successful transition will likely imply the 'replacement' of the existing constitution, if the constitutional replacement doctrine is applied rigidly, transitional justice mechanisms will always be held unconstitutional. This renders the application of the constitutional replacement doctrine in a syllogistic fashion unsuitable for the judicial review of transitional justice mechanisms, because this will defeat the project of transition in circumstances where political and institutional change is necessary, for example following conflict or a public loss of confidence in the old regime. Such an application of the doctrine may be appropriate for defending the constitution from abuses of the amending power, for example amendments by an incumbent President or party to stay indefinitely in power or to minimise political or judicial accountability, but not in the context of a legitimate process of transitional justice.

Secondly, I endorse the Court's reasoning that the adoption of transitional justice mechanisms under a permanent constitution is constitutional, provided those mechanisms limit essential principles of the constitution only to a degree proportionate to the degree to which they achieve their aims under the international and transnational legal framework for transitional justice. Constitutional courts can thus play a valuable role in constitutional transitions, providing the forum for a particular form of constitutional dialogue. As such, it is proper for them to assess whether adopted transitional justice mechanisms are suitable, necessary, and proportionate for achieving the specific goals of a constitutional transition. In order to play this role, constitutional courts should adopt an approach similar to that of the Colombian Constitutional Court, balancing the essential principles of the permanent constitution against principles recognised to belong to the international and transnational legal framework for transitional justice, entrenching the goals of transitional justice: stable and lasting peace, reconciliation, and 
the end of political conflict. Courts may undertake this evaluation by means of the principle of proportionality.

I support these claims in the following manner. First, I briefly explain the historical background of Colombia's internal conflict. Secondly, I describe the context and the content of Legislative Act 1/2012. Thirdly, I spell out the Colombian replacement doctrine as an example of a species of constitutional doctrine found more widely-the doctrine of 'unconstitutional constitutional amendments'. Fourthly, I analyse Judgments C-579/2013 and C-577/2014, showing that, while the traditional application of the replacement doctrine is not appropriate for evaluating the constitutionality of transitional justice mechanisms, the new approach is suitable to that end. Fifthly, I draw conclusions from the Colombian case and explore the extent to which they can be generalised in other cases of the transitional dilemma. Finally, I spell out why it is justified for constitutional courts to assess transitional justice mechanisms by balancing essential principles of the permanent constitution against basic goals of transitional justice with their source in the international and transnational framework for transitional justice.

\section{Historical Background of Colombia's Internal Conflict}

Since its independence from Spain in 1810, the political history of Colombia has been dominated by an endless fratricidal war. From the beginning of the nineteenth century until the middle of the twentieth century, war between the members of the two traditional parties, the conservatives and liberals, caused bloodshed on a scale comparable only with that of the Mexican revolution. This critical situation declined in the 1970s, when the parties signed an agreement for alternate power sharing with a formula called the National Front. According to this formula, the President was succeeded by a President from the opposing party. In spite of its benefits, this formula excluded any politics outside the consensus reached by conservative and liberal elites from the political process. This led to the impression, especially on the left wing of politics, that the political claims of the working class, indigenous peoples, and small farmers were excluded by traditional elites invested in the status quo. 'The only difference today between Liberals and Conservatives', wrote Colombian Nobel Prize winner Gabriel García Márquez, is that the Liberals go to mass at five o'clock and the 
Conservatives at eight.' ${ }^{19}$

The closed nature of the political system during the National Front was conducive to the emergence and consolidation of various guerrilla groups. At the beginning, the guerrillas fought under a kind of leftist political credo, bearing elements of Marxism and Maoism, which they proposed as an alternative to the Conservative-Liberal consensus. As a result, it might be said that the old war continued, but the parties changed their flags. Backed by the United States, the state tried to exterminate the guerrillas, which, on their part, received financial and ideological support from the then USSR and Cuba. Nevertheless, neither side was able to defeat the other. Thousands of deaths of members of the Army and civilians weakened Colombian society for decades. Crucially, the Colombian state has never had a monopoly on power over the whole national territory. The guerrillas have exercised de facto military control over some part of the national territory and have survived through different mutations. The most remarkable, following the fall of the Berlin Wall and the demise of the USSR, was the absolute loss of ideological direction, followed by a transformation into a lucrative business of organised crime, kidnapping, and drug trafficking.

Constant attacks by the guerrillas on landowners and the inability of the state to enforce state law in rural areas, gave rise to nationalist paramilitary groups to provide protection. Some of the most powerful of these groups formed the Colombian United Self-Defense Groups (known as AUC because of the initials of this name in Spanish, 'Autodefensas Unidas de Colombia'). Supported by the landowners, these groups intensively fought the guerrillas. Nevertheless, these groups also deployed a strategy of elimination of civilians who actually or allegedly supported the guerrillas and funded their activities through similar, nefarious means. These developments resulted in outrageous massacres and systematic violation of human rights.

\section{Transitional Justice under the 1991 Colombian Constitution}

The Constitution of 1991 emerged as a sign of hope against the backdrop of a beleaguered state with armed paramilitaries engaged in outright conflict and exercising de facto control over parts of the sovereign territory. The process of its formation was the first that can be considered democratic in the history of

${ }^{19}$ G García Márquez, One Hundred Years of Solitude (2006) 248. 
Colombia. This was the first constitution that did not represent an imposition by the victor on the vanquished. Representatives of the most heterogeneous groups and classes in Colombian society were able to participate in the formulation of its text. Its main motto was pluralism. The Constitution was designed to open up the political system and to guarantee the political participation of indigenous peoples, the working class, farmers, and members of guerrilla groups, such as the M-19, that demobilised before the election of a Constitutional Assembly in December 1990. In addition, the wide-ranging declaration of socio-economic rights with binding force compelled the state to work actively towards achieving a better level of social justice and distribution of wealth to benefit groups traditionally the subjects of discrimination. ${ }^{20}$

Nevertheless, even under the Constitution of 1991, the state lacked adequate political and military power to eradicate the guerrillas and other illegal groups, such as paramilitary groups. For this reason, two processes of transitional justice have been set in motion. The first began in 2005, the year in which the Congress passed Act 975/2005. This Act (and Judgment C-370/2006 of the Constitutional Court reviewing its constitutionality), along with some other legislation ${ }^{21}$ and administrative norms, ${ }^{22}$ established mechanisms for rendering the members of paramilitary groups judicially accountable and for enabling their victims to achieve clarification of the truth, compensation, and land restitution. Despite the fact that more than 35,000 members of paramilitary groups have so far demobilised under this process, it has been the target of strong criticism concerning impunity and the insufficiency of mechanisms for ensuring victim reparation and land restitution. ${ }^{23}$

The second process of transitional justice, the subject of this article, was inaugurated by Legislative Act $1 / 2012$. This Act contains an integrated system of transitional justice mechanisms designed to facilitate negotiations between the

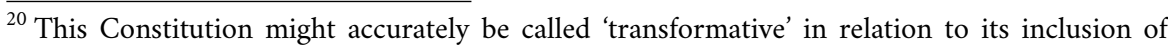
socio-economic rights aiming to ensure the satisfaction of basic needs of the least advantaged and vulnerable population. On this transformative dimension of the Constitution, see generally, C Rodriguez Garavito, 'Beyond the Courtroom: The Impact of Judicial Activism on Socioeconomic Rights in Latin America' (2010-2011) 89 Tex LR 1669.

${ }^{21}$ Particularly Legislative Acts 1424/2010, 1448/2011, and 1592/2012.

${ }^{22}$ Particularly Decree 1290/2008.

${ }^{23}$ For a holistic and comparative assessment of the mechanisms of this first transitional justice process, see, R Uprimny Yepes, MP Saffon Sanín, C Botero Marino \& E Restrepo Saldarriaga, Justicia transicional sin transición? Verdad, justicia y reparación para Colombia (2006). On the specific challenges of compensation to victims and land restitution, see N Summers, 'Colombia's Victims' Law: Transitional Justice in a Time of Violent Conflict?' (2012) 25 Harv HRJ 219.
} 
state and illegal groups, prevent impunity for serious war-related crimes, and provide guarantees of justice, truth, and compensation to victims. The Act grants, as instruments of transitional justice, five powers to Congress:

(1) An empowerment to give different treatment to the several illegal groups and state actors participating in the political conflict. The Legislative Act grants a competence to the legislature for giving privileges to the members of those guerrilla groups willing to sign a peace agreement.

(2) An empowerment to create judicial and extra-judicial procedures for prosecuting crimes, clarifying the truth, and ensuring compensation to the victims.

(3) An empowerment to create a truth commission, a particular extra-judicial institution whose outputs are recommendations without binding force.

(4) An empowerment to determine selection criteria for prioritising the prosecution of those 'most responsible' for systematically perpetrated crimes against humanity, genocide, and war crimes, and refraining from prosecuting other offences and agents, suspend sentences, and commute criminal penalties for 'extrajudicial sanctions' or 'special arrangements'.

(5) An empowerment to determine what crimes can be deemed as 'political offences' such that their perpetrators will remain eligible for future political participation. Article 3 makes it clear that crimes against humanity and genocide cannot be deemed political offences under this power.

The provisions introducing those empowerments state that these instruments of transitional justice can confer special benefits on members of illegal groups only if they have demobilised, signed a peace agreement, surrendered their weapons, acknowledged responsibility, and if they have contributed to uncovering the truth, the full reparation of the victims, and the release of hostages and minors illegally recruited.

\section{The Constitutional Replacement Doctrine}

In Judgments C-579/2013 and C-577/2014, the Colombian Constitutional Court had to decide whether the above transitional justice mechanisms were constitutional. Plaintiffs in both cases requested the Court to apply the constitutional replacement doctrine and to hold the Legal Framework for Peace unconstitutional under it. Before undertaking a critical analysis of these judgments, I will briefly explain the constitutional replacement doctrine. 
The replacement doctrine is a doctrine of 'unconstitutional constitutional amendment'. Doctrines of this sort rest on two propositions: first, that there are substantive limitations to the power to amend the constitution; and secondly, that constitutional and supreme courts have the competence to review constitutional amendments on substantive grounds, that is, to enforce substantive limitations on the amending power. ${ }^{24}$ Doctrines of unconstitutional constitutional amendments have been adopted across the world in recent decades. They have been employed in Europe, including Germany, France, Portugal, Turkey, Italy, the Czech Republic and Greece; in Latin America, including Brazil, Colombia, Argentina, El Salvador, Dominican Republic and Peru; in the Middle East, in Israel; in Asia, including India, Bangladesh, Nepal, Pakistan, Indonesia, Thailand, Cambodia, China, South Korea, Japan, and Taiwan; and in Africa, including South Africa, Zambia, Kenya, Zimbabwe, Tanzania, and Malawi. ${ }^{25}$

In Colombia, the constitutional replacement doctrine has been developed by the Constitutional Court to justify a power to review the content of constitutional amendments. The Colombian Constitution does not grant this power to the Court expressly. Articles 241 and 379 of the Constitution empower the Court to review constitutional amendments, but only on procedural grounds. The replacement doctrine is implied by means of a five-tiered argument developed in a line of authorities comprising Judgments C-551/2003, C-1200/2003, C-970/2004, C-153/2007, C-588/2009, C-141/2010, C-1056/2012 and C-10/2013.

The first premise of the doctrine is that the power to review compliance with amendment procedures entails a power to review the competence of the authority issuing the amendment. The second premise asserts that the power to amend the Constitution does not imply the power to replace it, but only to modify it. Thirdly, if this is so, then the Constitutional Court has the power to review whether the amending authority is in fact only modifying, rather than replacing the Constitution. Fourthly, only an analysis of content allows the Court to determine whether the Constitution has been modified or replaced. Finally, it follows from this that the power to review whether the Constitution has been replaced implies the competence to review the content of constitutional

\footnotetext{
${ }^{24}$ On this doctrine, see generally R Albert, 'Nonconstitutional Amendments' (2009) 22 Can J L \& Juris 5.

${ }^{25}$ For a detailed recent study, see, Y Roznai, Unconstitutional Constitutional Amendments: A Study of the Nature and Limits of Constitutional Amendment Powers, Doctoral thesis submitted to the Department of Law of the London School of Economics, 2014, <http://etheses.lse.ac.uk/915/1/Roznai_Unconstitutional-constitutional-amendments.pdf> [accessed 14 November 2014].
} 
amendments.

In Judgment C-551/2003, the Court ruled that the power to amend the Constitution comprises the power to introduce changes to any article of the constitutional text. However, these changes can neither imply a derogation of the Constitution, nor its replacement by a different one. The Court distinguished between the original constituent power and the amending power, stating that, while the original constituent power knows no legal constraints, the exercise of the amending power is a derivative power, which is limited in form and substance. $^{26}$ In Judgment C-1200/2003, the Court clarified that there can be 'partial' constitutional replacements. An amendment is a partial constitutional replacement if it is of great 'transcendence and magnitude' for the system. ${ }^{27}$ In Judgment C-970/2004, the Court explained that a constitutional amendment is a constitutional replacement if it replaces an essential element defining the identity of the Constitution. ${ }^{28}$ The Court also explained the test to be used to apply the replacement doctrine, with the structure of a legal syllogism. The major premise is the rule that a constitutional amendment is a constitutional replacement if it replaces an essential element of the Constitution. The minor premise is that a constitutional amendment replaces an essential element. If this condition is met, then it follows that the amendment is a constitutional replacement.

In Judgment C-1040/2005, the Court spelled out what is meant by an 'essential element'. An element is essential if it underpins several constitutional provisions or, in other words, it is essential if its content cannot be reduced to only one constitutional provision. An element that undergirds several different provisions forms part of the structure of the Constitution, rather than being an incidental feature. If such an element is replaced by a new opposite element, the new element will be in tension with several constitutional provisions. ${ }^{29}$ In

\footnotetext{
${ }^{26}$ In Judgment C-551/2003, the object of review was an Act calling for a referendum. The referendum was about several issues concerning the structure of the Congress and of the Public Administration, and the management of public funds. As such, the Act did not introduce any changes to the Constitution. It was the first part of a two-step amendment process, of which the referendum was the second step.

${ }^{27}$ The subject matter of Judgment C-1200/2003 was a Legislative Act that empowered the President to amend various laws with the purpose of adjusting them to a new adversarial criminal system that had been adopted at that time.

${ }^{28}$ In Judgment C-970/2004, the matter of review was again a Legislative Act empowering the President to amend various laws with the purpose of adjusting them to the new adversarial criminal system.

${ }^{29}$ In Judgment C-1040/2005, the Constitutional Court reviewed a Legislative Act derogating the prohibition of presidential re-election. The Act allowed the immediate re-election of the
} 
Judgments C-153/2007 and C-588/2009, the Court added that the replacement of an essential element would lead to a 'constitutional change of great magnitude'.

The Constitutional Court has used these criteria to declare the unconstitutionality of several constitutional amendments in the past. Until 2013, the Court consistently applied the replacement test as a legal syllogism. In Judgment C-1040/2005, the Court held that an amendment stipulating only one presidential re-election and, at the same time, empowering the Congress to enact a law that guarantees all candidates equal rights in the electoral campaign, did not replace the principles of the separation of powers, alternative exercise of political powers, or electoral equality. However, the Court declared unconstitutional an amending clause stating that, if the Congress failed to enact the law of electoral guarantees within two months, the Council of State, that is, the highest administrative court, ought to enact a regulation granting equality of rights during the elections. The Court determined that this grant of power to the Council of State replaced the principle of the separation of powers, which is an essential element of the Constitution and, consequently, ought to be considered as a constitutional replacement.

In Judgment C-588/2009, the Constitutional Court declared unconstitutional an amendment that automatically inducted a certain category of temporary employees of the Public Administration into the administrative career. As a consequence of the amendment, they gained tenure without passing the usual merit-based exam. The Court held that this amendment replaced two essential elements of the Constitution, namely, the principle of equality and the principle of merit, a constitutional principle governing the administrative career of tenured civil servants.

In Judgment C-141/2010, the Court declared unconstitutional an amendment granting the possibility of a presidential re-election to a third term. This was an ad hoc constitutional amendment instigated by the then Colombian President Alvaro Uribe with the purpose of making him eligible to run for the presidency for the third time. Making reference to certain aspects of the constitutional design concerning the appointment of high court judges and members of other state agencies, such as the Central Bank, the Court held that allowing a second presidential re-election would be tantamount to replacing the principle of checks and balances. It would also replace the principles of alternated exercise of political power, the equality among presidential candidates, and the generality of laws.

President and commanded the Congress to enact a law for the purpose of setting in place some electoral guarantees for opponents to the President in the presidential campaign. 
In Judgment C-1056/2012, the Court declared that an amendment excluding rules about conflict of interests of congressmen from the discussion and passing of constitutional amendments was a constitutional replacement, because it infringed basic constitutional principles concerning the respect of public morality in a democracy. In Judgment C-10/2013, on the other hand, the Constitutional Court declared that an amendment modifying certain rules concerning the distribution of income from mining taxes between administrative regions was not a replacement of the Constitution.

From the replacement jurisprudence, it appears that the 'essential elements' of the Constitution immune to replacement include the principle of separation of powers, ${ }^{30}$ legislative bicameralism, ${ }^{31}$ the elements of the rule of law including the principle of equality, the democratic principle, and the abstract and general nature of laws, ${ }^{32}$ the pre-eminence of the common good, ${ }^{33}$ the principles of popular sovereignty and deliberative democracy, ${ }^{34}$ the social state principle, ${ }^{35}$ and the principle of decentralisation of departments and cities. ${ }^{36}$

\section{A Critical Analysis of the Judgments C-579/2013 and $\mathrm{C}-577 / 2014$}

In Judgment C-579/2013, the matter under review was the provision in Act 1/2012 empowering the Congress to determine selection criteria for use by the Attorney General to give priority to the prosecution of those 'most responsible' for 'systematically perpetrated' crimes against humanity, genocide, and war crimes. According to the same criteria, the Attorney General may refrain from prosecuting 'all the cases', and may also suspend sentences and commute criminal penalties into 'extrajudicial sanctions' or 'special arrangements'. The plaintiff sought a declaration that the expressions 'most responsible', 'systematically perpetrated', and 'all the cases' implied a constitutional replacement. The plaintiff claimed that these expressions implicitly replaced an essential constitutional element, namely, the state duty to guarantee human rights protection for victims and society generally by means of the strict enforcement of criminal laws against

\footnotetext{
${ }^{30}$ Judgments C-970/2004, C-971/2004, C-1040/2005, C-141/2010, and C-1056/2012.

31 Judgment C-757/2008.

32 Judgments C-588/2009, C-141/2010, C-249/2012, and C-1056/2012.

${ }^{33}$ Judgment C-1056/2012.

${ }^{34}$ Judgment C-303/2010.

35 Judgment C-288/2012.

${ }^{36}$ Judgment C-10/2013.
} 
all human rights violations and all infringements of international humanitarian law. According to the plaintiff, Act 1/2012 would unconstitutionally empower the Congress to replace this essential element of the Constitution by restricting the state duty to enforce criminal laws against only some human rights violations and only some infringements of international humanitarian law, namely, the violations and infringements 'systematically perpetrated' by the 'most responsible agents'.

The Constitutional Court held that the state duty to guarantee human rights and to enforce criminal laws against human rights violations has the structure of a legal principle. In doing so, the Court employed a distinction between rules and principles increasingly recognised in legal theory, developed in particular by Ronald Dworkin and Robert Alexy. ${ }^{37}$ While rules stipulate a particular outcome whenever they apply, principles are optimisation requirements. Principles are norms that do not establish exactly what ought to be done, but require 'that something be realised to the greatest extent possible, given the legal and factual possibilities. ${ }^{38}$ The scope of what is legally possible is determined by weighing opposing principles, while factual statements about the case determine the scope of the factually possible. While rules apply by means of a legal syllogism, subsuming facts within a rule that dictates an outcome as a matter of 'if...then', principles are applied by means of balancing. In order to establish the 'greatest extent possible' to which a principle should be carried out, it is necessary to balance it against opposing principles accorded varying 'weight'. At this point, the Court introduced an innovation into its application of the replacement doctrine. The Court did not assess whether the provisions of the Legislative Act 01/2012 'denatured' the duty to guarantee human rights and enforce criminal laws as it had hitherto. Instead, the Court balanced this essential element of the Constitution against an opposing principle, namely, the goal of 'achieving a stable and lasting peace'.

On what grounds did the Court find that the goal of achieving a stable and lasting peace is a valid legal principle? The Court considered the large body of international legal principles concerning transitional justice as a valid legal framework for reviewing the constitutionality of Legislative Act 01/2012. On the basis of Article 93 of the Colombian Constitution, ${ }^{39}$ the Court considered a

\footnotetext{
${ }^{37}$ See e.g. R Alexy, A Theory of Constitutional Rights (2002), 44ff; R Dworkin, Taking Rights Seriously (1977) $14 \mathrm{ff}$

${ }^{38}$ Alexy, above n 37, 47.

39 International treaties and agreements ratified by the Congress that recognize human rights and that prohibit their limitation in states of emergency have priority domestically. The rights and duties mentioned in this Charter will be interpreted in accordance with international treaties on
} 
number of international and transnational legal instruments as binding. They belong to what Colombian jurisprudence terms the 'constitutional block', that is, the block of norms belonging to the international human rights treaties ratified by Colombia. As a monist jurisdiction, in Colombia norms belonging to the constitutional block are internally binding and ought to be applied by all judges and authorities, including the Constitutional Court. ${ }^{40}$ The framework not only refers to achieving a stable and lasting peace, but also spells out a set of rules and principles related to reparation of victims, restoration of public trust in state institutions, reconciliation, strengthening of democracy and the rule of law, acknowledging truth, and land restitution. Instruments belonging to this framework include the UN Declaration of Basic Principles of Justice for Victims of Crime and Abuse of Power, ${ }^{41}$ the 1997 UN Human Rights Commission Set of Principles for the Protection and Promotion of Human Rights Through Action to Combat Impunity (also known as the Joinet Principles), ${ }^{42}$ the UN Basic Principles and Guidelines on the Right to a Remedy and Reparation for Victims of Gross Violations of International Human Rights Law and Serious Violations of International Humanitarian Law, ${ }^{43}$ the 2006 UN Security Council Resolution 1674 (in which the importance of preventing conflict through development and democracy was stressed), ${ }^{44}$ the 2011 Report of the Secretary-General of the UN Security Council titled The rule of law and transitional justice in conflict and post-conflict societies, ${ }^{45}$ and other sources of international human rights law, international humanitarian law, and Inter-American human rights law.

The international and transnational framework also provides suitable balancing criteria to measure the proportionality of specific transitional justice mecha-

\footnotetext{
human rights ratified by Colombia'.

${ }^{40}$ There are similar provisions in other constitutions. See, e.g. Art. 5 LXXVIII $₫ 2^{\circ}$ and $\$ 3^{\circ}$ of the 1988 Constitution of Brazil: para 2: 'The rights and guarantees expressed in this Constitution do not exclude others deriving from the regime and from the principles adopted by it, or from the international treaties in which the Federative Republic of Brazil is a party'; para 3: 'International human rights treaties and conventions which are approved in each House of the National Congress, in two rounds of voting, by three fifths of the votes of the respective members shall be equivalent to constitutional amendments'.

${ }^{41}$ GA Res 40/34, 29 November 1985.

${ }^{42} \mathrm{~L}$ Joinet, Question on the impunity of perpetrators of human rights violations (civil and political): Revised final report prepared by Mr. Joinet to Sub-Commission decision 1996/119, UN Doc E/CN.4/Sub.2/1997/20/Rev.1, 2 October 1997.

${ }^{43}$ GA Res 60/147, 16 December 2005.

${ }^{44}$ SC Res 1674, 28 April 2006.

${ }^{45} \mathrm{~B}$ Ki-Moon, United Nations Secretary-General, The rule of law and transitional justice in conflict and post-conflict societies: Report of the Secretary-General, UN Doc S/2011/634, 12 October 2011.
} 
nisms. In this regard, the Court employed a version of the so-called 'rule of balancing' to reconcile the State duties to guarantee human rights and enforce criminal laws with the goal of achieving a stable and lasting peace. According to this rule, 'the greater the degree of non-satisfaction of, or detriment to, one principle, the greater must be the importance of satisfying the other. ${ }^{46}$ The Court came to the conclusion that the degree of detriment to the state duty to protect human rights and enforce criminal laws against human rights violations is less than the importance of satisfying the goal of a stable and lasting peace and revealing the truth. The Court reasoned in particular that prosecuting only the 'most responsible' agents is a suitable approach to assure the non-recurrence of crimes, dissolve criminal macro-organisations, and reveal patterns of human rights violations. At the same time, this policy of criminal prosecution represents only a mild interference with the state duty to protect human rights, because it does not amount to an absence of investigation of war crimes, genocide and human rights violations. It only empowers the state with the discretion to focus its attention on 'those agents who played an essential role in the perpetration' of those violations.

Further, the Court held that the powers vested in the legislature expressed a proportionate relation between the duty to guarantee human rights and enforce criminal laws and the goal of achieving a stable and lasting peace, provided their exercise meets certain conditions. First, the relevant statute must guarantee victims: a transparent selection process of the cases to be prosecuted; an impartial, timely, inclusive, and effective criminal investigation; judicial mechanisms to appeal decisions concerning the selection of cases; legal aid; the right to know the truth about the cases not selected by means of extra-judicial mechanisms; the right to compensation in full; and the right to find out where the remains of family members are. Secondly, the legislation must give priority to the prosecution of extra-judicial executions, torture, forced disappearances, sexual violence against women, forced displacement, and illegal recruitment of children, when these offences can be deemed as crimes against humanity, genocide, or war crimes systematically perpetrated. Thirdly, only illegal groups that 'effectively contributed to the clarification of truth, reparation of the victims, liberation of kidnapped people and child soldiers' may enjoy the benefits of transitional justice mechanisms. Finally, total suspension of penalties cannot operate for 'the most responsible agents for the perpetration of crimes against humanity, genocide, and war crimes systematically perpetrated'.

\footnotetext{
${ }^{46}$ Alexy stated the rule with this formulation in A Theory of Constitutional Rights. See Alexy, above n 37, 47.
} 
On 6 August 2014, in Judgment C-577/2014, the Constitutional Court upheld the constitutionality of Article 3 of Act 1/2012. The plaintiff in this case argued that there was an unconstitutional omission in Article 3 of the Act. Article 3 empowers the Congress to deem certain offences 'political crimes' and to determine which offences should be so deemed. The effect of the provisions is that those who have committed 'political crimes' but who have demobilised and reintegrated into civil society in the course of the peace process remain eligible to participate in politics in the future. The Article sets a constraint to the exercise of this power, namely, that crimes against humanity and genocide cannot be deemed 'political crimes'. The plaintiff maintained that, by excluding including war crimes, transnational and drug trafficking offences, and acts of terrorism in the list of offences that cannot be deemed 'political crimes', this Article replaces the participatory democratic framework of the Constitution. This is an essential element of the Constitution and, in turn, one of its essential elements is the requirement of minimum moral standards for the candidates who intend to represent the people as political office-holders.

The Court did not agree with the plaintiff. The Court held that the amending power did not replace the participatory democratic framework of the Constitution. By contrast, not including the above mentioned offences in the list of crimes that cannot be deemed to be political crimes enhances the possibilities of future political participation for participants in the current and historical conflict. This is a suitable means to achieve two of the goals of transitional justice, namely, reconciliation and a stable and lasting peace. ${ }^{47}$ In a dissenting opinion, two judges (Ortíz and Palacio) took this position to an extreme and argued that the Court should have declared that Article 3's prohibition of deeming crimes against humanity and genocide as political crimes was unconstitutional. Those judges reasoned that this prohibition replaced the constitutional principle of participatory democracy and rendered impossible the goal of achieving a stable and lasting peace. Political exclusion, they maintained, is incompatible with participatory democracy and is a cause of political conflict.

\footnotetext{
${ }^{47}$ At the time of submission of this article, the Constitutional Court has not made public the complete text of Judgment C-577 of 2014. Nevertheless, the way the press release is drafted provides grounds to anticipate that the justification of the judgment will use the balancing approach again. For instance, there is an explicit reference to the transitional justice goals of reconciliation and stable and lasting peace as reasons justifying the exclusion of other crimes that cannot be deemed to political offences.
} 


\section{Abusive Constitutionalism and Transitional Justice as Different Frameworks for Assessing a 'Constitutional Replacement'}

Despite the fact that Colombian law has the structure and foundations of a civil law system, since Judgment C-836/2001, the Constitutional Court has followed a doctrine of precedent in constitutional matters. ${ }^{48}$ Had the Court followed this doctrine strictly, it should have applied the traditional syllogistic methodology of the replacement test and it should have declared unconstitutional the provisions of Legislative Act 01/2012 under scrutiny in the cases C-579/2013 and C-577 of 2014. Recall that in Judgment C-588/2009, the Constitutional Court declared that an amendment automatically including a certain category of temporary public sector employees (appointed by the then incumbent government) in the administrative tenure-track without the customary exam violated the principle of equality and was unconstitutional under the replacement doctrine. The infringement upon the principle of equality generated by that amendment, however, was less severe than the one engendered by granting immunity from prosecution to perpetrators of human rights violations and other serious criminal offences under the concept of 'political crime'. Accordingly, under the precedent of Judgment C-588/2009, the Court in Judgment C-579/2013 should have declared unconstitutional the possibility of renouncing the duty of criminal prosecution in certain cases.

Again, in Judgment C-1056/2012, the Constitutional Court had declared the unconstitutionality of an amendment stipulating that rules about congresspersons' conflicts of interests would not be applicable in the discussion and passing of constitutional amendments. The Court held that this amendment infringed basic constitutional principles concerning an essential element of the Constitution, namely, the respect of public morality in a democracy. Again, this infringement upon public morality requirements concerning the character and behaviour of political representatives in a democracy is less severe than the one prompted by the possibility of allowing perpetrators of war crimes, transnational and drug trafficking offences, and acts of terrorism to participate in politics. Accordingly, under this precedent the Court should have declared the grant of power unconstitutional in Judgment C-577 of 2014.

However, the Court was correct in transforming the replacement test into a proportionality analysis in Judgment C-579/2013. The traditional syllogistic test

${ }^{48}$ See C Bernal, 'Precedent in Colombia', in E Hondius (ed), Precedent and the Law (2007) 311, 311-22. 
is inappropriate for applying the replacement doctrine in a transitional justice framework. The traditional test might be appropriate for a non-transitional context. As David Landau put it recently, strategies such as the Colombian replacement test aim to defend democracy against 'abusive constitutionalism. ${ }^{49}$ Landau refers with this term to the the use of mechanisms of constitutional change in order to make a state significantly less democratic than it was before. ${ }^{50}$ Incumbent governments use this strategy for making themselves difficult to dislodge from power or to render themselves judicially or politically less accountable. In Colombia, the traditional replacement test has proved to be an effective tool against constitutional amendment proposals, generally propelled by the executive, with the purpose of accumulating powers in the figure of the President, that is achieving a state of 'hyper-presidentialism' which renders the constitutional notion of checks and balances inoperative. Judgments C-588/2009 and C-1056/2012 are examples of this use of the constitutional replacement doctrine. So too is Judgment C-141/2010, in which the Constitutional Court declared the unconstitutionality of an amendment granting former President Alvaro Uribe the chance of re-election to a third term.

The 'abusive constitutionalism' scenario is entirely different from that of a transitional justice process. The aim of amendment in a process of constitutional transition is not to alter the constitution in order to undermine democracy, but to introduce changes in the constitutional framework to address deep political issues-issues which the polity has been unable to solve within the existing framework, but which do not require the framework to be abandoned entirely as it is in fundamental respects sound. For this reason, as Posner and Vermeule claim, "[e]very transition creates a divide between the old regime and the new regime. ${ }^{51}$ The syllogistic replacement test is therefore too strict: it does not allow transitional justice mechanisms to operate in an effective manner. Further, the use of the replacement test within this context lacks the justification of its employment against instances of abusive constitutionalism.

Three linked questions arise. First, is substantive constitutional review of amendments by a constitutional court still justified in the context of a process of transitional justice? Secondly, if so, what would be an appropriate legal framework and methodology for carrying out this type of review? Finally, on this basis, how should the transitional dilemma be solved?

\footnotetext{
${ }^{49}$ D Landau, 'Abusive Constitutionalism' (2013) 47 UC Davis LR 189.

${ }^{50}$ Ibid, 195.

51 EA Posner \& A Vermeule, ‘Transitional Justice as Ordinary Justice’ (2004) 117 Harv LR 762, 765.
} 
In answer to the first question, the aim of the various doctrines of unconstitutional constitutional amendments is to protect human rights, the rule of law, and democracy, from attempts to degrade their basic structure and entrenchment in the constitution. In a conflictual society, such attempts might well be dressed up as transitional justice mechanisms. The power to amend the constitution does not imply the power to denature its conceptual fabric by violating its fundamental principles, even for the sake of starting a process of transitional justice, and this justifies the substantive review by a constitutional court even of transitional justice mechanisms. The power to amend presupposes the existence of a constitution prior to and subsisting after its exercise. Thus, not even transitional justice mechanisms should be allowed to transform the constitution into a different kind of entity by depriving it of any of its essential conceptual elements: human rights, the rule of law, and democracy. That would involve not a process of constitutional amendment, but a radical break with the constitutional order and the establishment of a new one. The notion of amending a permanent constitution, as opposed to introducing an interim constitution and a new constitutional assembly, is to effect the transition within the general framework of the existing constitution and its institutions. This being the case, substantive review by a constitutional court is appropriate to secure that the amending power abide by this constraint.

Constitutional courts have indeed played an increasing role in constitutionmaking processes. ${ }^{52}$ The paradigmatic example of this is s 71(3) of the 1993 South African Interim Constitution, granting power to the Constitutional Court to certify that the new Constitution complied with the 'constitutional principles' stated in the Interim Constitution. Reflecting on that example, Arato correctly suggests that constitutional courts are institutions suitable for guaranteeing at least procedural fairness in a constitution making process. ${ }^{53}$

In a transitional justice process under a permanent constitution, a constitutional court has two functions. On the one hand, it has the power (and duty) to guard the essential principles of the permanent constitution from degradation. On the other hand, it has a constitution-making power for guaranteeing the fairness of the transition. A transition aims to strengthen or create state institutions, mechanisms, and procedures for protecting human rights, democracy, and the rule of law, and those are exactly the substantial principles that a constitutional court is designed to protect. Furthermore, constitutional courts play a

\footnotetext{
${ }^{52}$ A Arato, 'Redeeming the Still Redeemable: Post Sovereign Constitution Making' (2009) 22 IJ of Politics, Culture and Society 427, 433.

${ }^{53}$ Ibid.
} 
role providing 'argumentative representation' of the people. ${ }^{54}$ They represent the people in making constitutional decisions on the ground of rational arguments, grounded in notions of human rights or the rule of law, for example, as opposed to decisions by the political representatives of the people, which are grounded in negotiation of interests. As the Constitutional Court acknowledged in Judgment C-579/13, a transitional justice process instantiates a conflict between justice and peace. In a deliberative democracy, this conflict should not only be solved on the basis of political negotiations (concerning the interests of the parties in conflict), but also through rational arguments concerning the interpretation of the legal framework that sets the boundaries for political negotiations. The Constitutional Court is a forum for this second, important form of debate.

Concerning the second question, the principle of proportionality provides a plausible methodology for resolving collisions between the essential principles of a permanent constitution and the basic goals of transitional justice. Alongside the international instruments relied upon by the Constitutional Court in Judgment C-579/2013, goals of transitional justice and criteria for balancing these goals and constitutional principles can also be found in the Report of the Secretary-General of the of the United Nations entitled The rule of law and transitional justice in conflict and post-conflict societies of 23 August 2004. ${ }^{55}$ The report identifies the enforcement of criminal justice and the implementation of truth-telling, reparations, institutional reform, and vetting as main elements of transitional justice. $^{56}$ The pillars of the international legal system, that is, international human rights law, international humanitarian law, international criminal law, and international refugee law, also prescribe a set of standards useful to test the

\footnotetext{
${ }^{54}$ On the Constitutional Court as argumentative representative of the people, see generally, $\mathrm{R}$ Alexy, 'Balancing, Constitutional Review and Representation' (2005) 3(4) Int J Const L 572.

${ }^{55} \mathrm{~K}$ Annan, United Nations Secretary-General, The rule of law and transitional justice in conflict and post-conflict societies: Report of the Secretary-General, UN Doc S/2004/616, 23 August 2004. Other international documents on topics related to transitional justice include: UN Commission on Human Rights, Updated Set of Principles for the Protection and Promotion of Human Rights through Action to Combat Impunity, UN Doc E/CN.4/2005/102/Add.1, 8 February 2005 and the accompanying reports by D Orentlicher, Independent Study on Best Practices, Including Recommendations, to Assist States in Strengthening Their Domestic Capacity to Combat All Aspects of Impunity, UN Doc E/CN.4/2004/88, 27 February 2004 and Report of the Independent Expert to Update the Set of Principles to Combat Impunity, UN Doc E/CN.4/2005/102, 18 February 2005; GA Res 60/147, Basic Principles and Guidelines on the Right to a Remedy and Reparation for Victims of Gross Violations of International Human Rights Law and Serious Violations of International Humanitarian Law, 16 December 2005.

${ }^{56} \mathrm{~K}$ Annan, United Nations Secretary-General, The rule of law and transitional justice in conflict and post-conflict societies: Report of the Secretary-General, UN Doc S/2004/616, 23 August 2004, 9.
} 
proportionality of transitional justice mechanisms. Given that Colombia is a member of the Inter-American System of Human Rights, ${ }^{57}$ the standards set by the Inter-American Court of Human Rights case law are directly binding. These include cases like Barrios Altos and Almonacid, in which the Court acknowledged the victim's right to reparation despite the existence of domestic amnesty laws, ${ }^{58}$ and Reports 28 and 29 of 1992 of the Inter-American Commission on Human Rights, concerning the amnesty laws in Argentina and Uruguay. ${ }^{59}$

The transnational law concerning transitional justice fleshes out the minimum standards for a transitional justice process, of which a domestic constitutional court can properly take cognisance for the purposes of balancing. ${ }^{60}$ Constitutional and international courts operate in a transnational legal environment in which they cannot disregard structures of international law and cross-national and comparative references. ${ }^{61}$ Transnational law concerning transitional jus-

${ }^{57}$ On sources of the Inter-American System of Human Rights on transitional justice, see, AE Dulitzky, 'The Inter-American Commission on Human Rights', in Due Process of Law Foundation, Victims Unsilenced: The Inter-American Human Rights System and Transitional Justice in Latin America (2007) 129-50; D Cassel, 'The Inter-American Court of Human Rights', ibid, 151-66. There are also sources concerning transitional justice in the framework of the European system of human rights. On the case law of the European Court of Human Rights on the matter, see generally, E Brems, 'Transitional Justice in the Case Law of the European Court of Human Rights' (2005) 11 IJ Trans J 282.

${ }^{58}$ Barrios Altos v Peru (2001) IACtHR Ser C No 75; Almonacid Arellano et al v Chile (2006) IACtHR Ser C No 154.

59 'Report 28/92, Cases 10.147, 10.181, 10.240, 10.262, 10.309 and 10.311, Argentina, October 2, 1992', in Inter-American Commission of Human Rights, Annual Report 1992-93; 'Report 29/92, Cases 10.029, 10.036, 10.145, 10.305, 10.372, 10.373, 10.374 and 10.375, Uruguay, October 2, 1992', ibid.

${ }^{60}$ In Azanian Peoples Organization (AZAPO) and Others $v$ President of the Republic of South Africa and Others 1996 (8) BCLR 1015, the South African Constitutional Court considered the international and transnational legal framework on transitional justice for reviewing the constitutionality of section 20(7) of the Promotion of National Unity and Reconciliation Act 34 of 1995. This section empowered the Committee on Amnesty established by the Act to grant amnesty to a perpetrator of an unlawful act associated with a political objective and committed prior to 6 December 1993. The section also determined the effects of the amnesty. The Court upheld the constitutionality of the section on the basis that it implied a limitation to the right to access to court justifiable by ss 22, 33(1) and (2), and the epilogue of the interim Constitution. Despite the fact that the Court ought to consider the constitutionality of that section only against the interim Constitution, speaking for the majority, in his opinion Mahomed DP cited the use of amnesty for criminal acts in the transitional justice processes in Chile, Argentina and El Salvador (paras 22-24). He also acknowledged that the interim constitution directed the Court 'to "have regard" to public international law if it is applicable to the protection of the' fundamental rights entrenched in chapter three of that constitution (para 27). However, Mahomed DP considered that none of the international instruments quoted by the applicants assisted their case.

${ }^{61}$ On this concept of transnational law, see VC Jackson, Constitutional Engagement in a Transnational 
tice makes it clear that the mechanisms of prosecutions, truth-telling, reparation, institutional reform, and vetting should be approached holistically, as they constitute a system designed to achieve several goals that may be in tension. Those goals include providing recognition and compensation to victims, promoting civic trust and reconciliation, strengthening democracy, ${ }^{62}$ achieving peace, ${ }^{63}$ punishing wrongdoers, forcing individuals to 'disgorge property that was wrongfully acquired, ${ }^{64}$ land restitution, collective and inclusive nation building, ${ }^{65}$ and redressing socio-economic grievances. ${ }^{66}$

A constitutional review of the transitional justice mechanisms implemented by a constitutional amendment should likewise adopt a holistic approach. ${ }^{67}$ The constitutional court should review whether the transitional justice framework has legitimate goals, whether the transitional justice mechanisms are suitable and necessary means to achieve those goals, and whether there is a proportional balance between them and the essential principles of the permanent constitution that are infringed in the process.

In order to undertake this analysis, a constitutional court can employ the principle of proportionality, including, its three sub-principles of suitability, necessity, and proportionality in the narrow sense. ${ }^{68}$ Within this context, these sub-principles establish a requirement that each transitional justice mechanism ought to meet. The sub-principle of suitability requires that the relevant mechanism contribute to the achievement of one of the goals of transitional

Era (2009) 63. On transnational constitutional law, see also, M Tushnet, 'The Inevitable Globalization of Constitutional Law' (2009) 49 Va JIL 985.

${ }^{62} \mathrm{P}$ de Greiff, 'Theorizing Transitional Justice', in M Williams, R Nagy \& J Elster (eds), Transitional Justice (2012) 31.

${ }^{63}$ J Elster, 'Justice, Truth, Peace', in M Williams, R Nagy \& J Elster (eds), Transitional Justice (2012) 78, 80. See also C Turner, 'Delivering Lasting Peace, Democracy and Human Rights in Times of Transition: The Role of International Law' (2008) 2 IJ Trans Just 126, 142.

${ }^{64}$ Posner \& Vermeule, above n 51, 766.

${ }^{65}$ See, W Kymlicka, 'Transitional Justice, Federalism, and the Accommodation of Minority Nationalism', in P Arthur, Identities in Transition: Challenges for Transitional Justice in Divided Societies (2014) 303.

${ }^{66}$ D Sankey, 'Towards Recognition of Subsistence Harms: Reassessing Approaches to Socioeconomic Forms of Violence in Transitional Justice', (2014) 8 IJ Trans J 121; I Muvini, 'Sitting on Powder Kegs: Socioeconomic Rights in Transitional Societies' (2009) 3 IJ Trans J 163.

${ }^{67}$ On the advantage of a holistic approach to the mechanisms of transitional justice, see, P de Greiff, 'A Normative Conception of Transitional Justice' (2010) 50 Politorbis 17, 19.

${ }^{68}$ On these sub-principles, see, among many others: B Schlink, 'Proportionality (1)' in M Rosenfeld \& A Sajó (eds), The Oxford Handbook of Comparative Constitutional Law (2012) 718, 721; A Stone Sweet \& J Mathews 'Proportionality, Balancing and Global Constitutionalism' (2008) 47 Col JTL 72, 75; A Barak, Proportionality: Constitutional Rights and their Limitations (2012) 3. 
justice. The sub-principle of necessity requires that the mechanism be the least restrictive of all means (regarding the essential principle of the constitution that becomes limited) that are equally suitable to achieve the pursued end.

Finally, the goals of transitional justice might conflict with each other. For instance, punishment to wrongdoers can conflict with achieving peace, ${ }^{69}$ and vetting individuals can conflict with inclusive democracy and empowering the state to use skilled administrative staff. ${ }^{70}$ They can also collide with essential principles of the permanent constitution. The sub-principle of proportionality in the narrow sense is an appropriate standard for solving these collisions. It requires that each transitional justice mechanism achieve its pursued end to a degree that justifies the extent of its interference with other transitional justice goals and with the essential principles of the permanent constitution. In this respect, for example, it would not be disproportionate in the narrow sense to allow members of the guerrilla that admitted to minor drug offences to participate in politics, but it would be clearly disproportionate to allow perpetrators of human rights violations to become high ranked officials of the Army. International transitional justice principles, such as the Joinet principles, provide balancing criteria useful for the test of proportionality in the narrow sense. For example, Principle 28 (Restrictions on the Practice of Amnesty) states:

When amnesty is intended to establish conditions conducive to a peace agreement or to foster national reconciliation, it shall be kept within the following bounds: (a) The perpetrators of serious crimes under international law and the perpetrators of gross and systematic violations may not be included in the amnesty unless the victims have been unable to avail themselves of an effective remedy and obtain a fair and effective decision; (b) Insofar as it may be interpreted as an admission of guilt, amnesty cannot be imposed on individuals prosecuted or sentenced for acts connected with the peaceful exercise of their right to freedom of opinion and expression. When they have done nothing but exercise this legitimate right, as guaranteed by articles 18 to 20 of the Universal Declaration of Human Rights and 18, 19, 21 and 22 of the International Covenant on Civil and Political Rights, the law shall consider any judicial or other decision concerning them to be null and void; their detention shall be ended unconditionally and without delay; (c) Any individual convicted of

\footnotetext{
${ }^{69}$ Elster, above n 63, 96.

${ }^{70}$ Posner \& Vermeule, above n 51, 766.
} 
offences other than those laid down in paragraph (b) of this principle who comes within the scope of the amnesty is free to refuse it and request a retrial if he has been tried without benefit of the right to a fair hearing guaranteed by articles 10 and 11 of the Universal Declaration of Human Rights and articles 9, 14 and 15 of the International Covenant on Civil and Political Rights or if he has been subjected to inhuman or degrading interrogation, especially under torture. ${ }^{71}$

This principle offers an example of criteria that can be used for achieving a balance between the essential constitutional principles of enforcement of criminal law, protection of the rights of the victims and fair trial rights, on the one hand, and the transitional justice goal of achieving a lasting peace, on the other. These criteria can also be employed by courts to assess the proportionality in the narrow sense of peace agreements containing amnesty clauses as transitional justice mechanisms.

\section{Conclusion}

Recall that according to the transitional dilemma, if the transition is successful the permanent constitution is replaced; if the permanent constitution remains in place, transition is rendered impossible. This defeats the notion of transitional justice within the framework of a permanent constitution, which is a major obstacle for both transitional justice and constitutionalism. The solution presented here recognises that a successful transition is likely to imply the replacement of the existing constitution with something substantially different, albeit within a process broadly circumscribed by the permanent constitution. That is, where there is no suspicion of 'abusive constitutionalism' the emphasis, at least, of the enquiry into the constitutionality of a constitutional amendment shifts from substance to process. Given that constitutional courts are appointed to provide argumentative representation of the people, it is still justified for them to assess whether the transitional justice mechanisms adopted are suitable, necessary, and proportionate to achieve the specific goals of a transition. In order to play this role, constitutional courts should balance the essential principles of the permanent constitution against the relevant goals of transitional justice, which may legitimately be drawn from international and transnational law, especially where

\footnotetext{
${ }^{71} \mathrm{~L}$ Joinet, Question on the impunity of perpetrators of human rights violations (civil and political): Revised final report prepared by Mr. Joinet to Sub-Commission decision 1996/119, UN Doc E/CN.4/Sub.2/1997/20/Rev.1, 2 October 1997. See also, Principles 19 and 20.
} 
such norms are binding on the constitutional court (as in a monist system like Colombia). Courts may undertake this evaluation by means of the principle of proportionality. The use of this principle provides the following solution for the transitional dilemma: the adoption of transitional justice mechanisms under a permanent constitution is substantively constitutional if and only if those mechanisms limit essential principles of the constitution in a degree that is proportionate to the degree in which they achieve the goals they seek, which ought to be legitimate under the international and translational legal framework for transitional justice. 